\title{
Analisis Kinerja Keuangan Koperasi Unit Desa Langgeng Desa Inauga Kecamatan Mimika Baru Kabupaten Mimika
}

\author{
Anton Gobai \\ Tinneke M Tumbel \\ Dantje Keles \\ Jurusan Ilmu Administrasi Program Studi Ilmu Administrasi Bisnis \\ Fakultas Ilmu Sosial dan Politik Universitas Sam Ratulangi \\ enakidagobai@gmail.com
}

\begin{abstract}
This study aims to determine the structure of KUD in terms of liquidity, solvency, and profitability. While the benefits that the author can provide to the cooperative are as a matter of consideration for KUD leaders to take policies as meeting the capital requirements of the $K U D$. how much influence the short-term and long-term debt on cooperative solvency in accordance with the problems stated and supported by a review of the literature on capital, capital structure and type of ratio analysis that the authors take this conclusion is not the achievement of solvency ratios due to increased fund and cost profitability collection methods used in this study are interviews (data collection with direct interviews with parties related to the data needed) and (cooperative financial statements). In analyzing the data the writer uses descriptive analysis method. Based on the results of this study there are those that cause the current to fluctuate ratio from year to year some of the working capital invested in the ratio is not smooth. Judging from the cash ratio it is also known that the condition of cooperative liquidity is still low due to the lack of effective cooperative spending policies, increasing the solvency ratio of cooperatives from year to year caused by an increase in the role of own capital compared to foreign capital. While an increase in profitability ratios is caused by an increase in profits achieved by cooperatives, this means that cooperatives have been efficient in their use.
\end{abstract}

Keywords: Liquidity, Solvability and Rent ability

\section{Pendahuluan}

Koperasi dikenal sebagai suatu bentuk perusahaan yang bukan milik perseorangan, bukan milik investor tetapi milik anggota. Dengan adanya koperasi, perekonomian di Indonesia berkembang semakin baik, sehingga dapat memajukan usaha bersama dan mensejahterakan kehidupan anggota. Pada dasarnya setiap usaha, koperasi dalam menjalankan usahanya selalu membutuhkan dana atau modal. Dengan modal yang ada digunakan untuk mendapatkan keuntungan yang dikelola secara lebih efisien.

Dalam pencapaian tujuan koperasi, maka koperasi harus mampu mempertahankan eksistensi-nya ditengah usahanya. Oleh karena itu, koperasi memerlukan penanganan yang benar-benar efektif dan efisien dalam segala aspek kegiatannya. Setiap koperasi harus mampu melihat kondisi lingkungan organisasinya untuk mempertahankannya eksistensinya. Salah satu hal yang dapat dilakukan 
koperasi dalam menghadapi persaingan yang semakin ketat adalah mengupayakan kinerja keuangan yang baik dan sehat.

Kinerja keuangan koperasi adalah hasil prestasi kerja dari koperasi pada periode tertentu dalam usaha mencapai daya guna dan hasil guna dalam pengembangan kegiatan usaha setinggitingginya yang dapat dilihat melalui kepemilikan modal sendiri dan data keuangan koperasi yang terdiri dari neraca dan laporan. Sebagai manajer koperasi dituntut dapat menangani perencanaan, pengendalian serta mampu menganalisis kinerja keuangan yang telah mampu dicapai saat ini sebagai acuan untuk penetapan laporan keuangan pada tahun mendatang.

Kinerja keuangan adalah suatu penilaian terhadap laporan keuangan perusahaan yang menyangkut posisi keuangan perusahaan serta pertumbuhan terhadap posisi keuangan tersebut. Kinerja keuangan didefinisikan juga sebagai ukuran-ukuran tertentu yang dapat mengukur keberhasilan suatu perusahaan dalam menghasilkan laba. Kinerja keuangan perusahaan merupakan hasil dari banyak keputusan individual yang dibuat secara terus menerus oleh manajemen. Upaya meningkatkan kinerja keuangan sangat terkait dengan tujuan manajemen keuangan. Dalam membahas metode penilaian kinerja keuangan perusahaan harus didasarkan pada data keuangan yang dipublikasikan yang dibuat sesuai dengan prinsip akuntansi keuangan yang berlaku umum.

Laporan keuangan mempunyai peranan penting bagi setiap entitas sebagai acuan penetapan kebijakan keuangan. Sebagaimana Koperasi Unit Desa Langgeng Desa Inauga Kecamatan Mimika Baru Kabupaten Mimika dalam mencapai kinerja keuangan koperasi yang baik, maka diperlukan penetapan kebijakan keuangan yang tepat. Hal ini dilakukan dengan memandang perekonomian yang mengalami kondisi sulit untuk berkembang. Kinerja keuangan koperasi pada posisi seimbang atau bertahan dapat dikatakan sudah bagus, apalagi hingga bisa berkembang melebihi ketentuan standar Kementerian Koperasi dan UKM, yang mana akan membawa koperasi ke arah tercapainya tujuan untuk mensejahterakan anggotanya dengan peningkatan sisa hasil usaha (SHU).

Laporan keuangan tersebut akan lebih berarti bagi pihak-pihak yang berkepentingan apabila data tersebut dibandingkan untuk dua periode atau lebih dan kemudian dianalisis. Dapat mengadakan analisis terhadap neraca dan laporan perhitungan hasil usaha pada koperasi dapat diketahui tentang komponen keuangan mana yang mengalami suatu permasalahan, sehingga dapat diketahui cara memecahkan masalah yang timbul untuk mencapai kemajuan di masa yang akan datang.

Analisis keuangan merupakan suatu proses yang bertujuan menentukan ciri-ciri 
yang penting tentang kinerja keuangan dan kegiatan koperasi berdasarkan data yang ada. Tujuan utama analisis kinerja keuangan untuk memperoleh pandangan yang lebih baik tentang masalah operasional dan keuangan yang dihadapi koperasi. Kinerja keuangan yang dinilai melalui rasio keuangan dapat memberi gambaran tentang sejarah koperasi dan posisi keuangan koperasi pada saat itu.

Ada beberapa teknik dalam menganalisis laporan keuangan koperasi salah satunya dengan analisis rasio keuangan, yaitu rasio likuiditas, rasio solvabilitas, dan rasio rentabilitas (profitabilitas) merupakan indicator dari analisis keuangan secara menyeluruh. Dengan mengetahui tingkat likuiditas, solvabilitas, dan rentabilitas (profitabilitas), maka menunjukkan kekayaan koperasi dan kemampuan koperasi yang dapat menjamin terhadap hutang-hutangnya serta kemampuan koperasi untuk menghasilkan keuntungan yang bernilai, di mana keuntungan ini akan kembali lagi untuk para anggotanya melalui sisa hasil usaha (SHU).

Dalam penelitian Ini Penulis menitikberatkan pada Koperasi Unit Desa didirikan untuk meneliti Kinerja Laporan Keuangan Pada Koperasi Bukan di Perusahaan Karena penulis Lebih Ingin Mengetahui Lingkungan Kondisi Perkembangan Pertumbuhan Koperasi dan Menilai laporan keuangan Pertanggungjawaban pengurus pada Koperasi Unit Desa Langgeng Inauga.
Dari uraian diatas penulis ingin menganalisis kinerja keuangan koperasi untuk menilai kinerja keuangan dalam mengantisipasi masa yang akan dating, oleh karena itu, penulis mengambil judul: "Analisis Kinerja Keuangan Koperasi Unit Desa (Kud) Langgeng Desa Inauga Kecamatan Mimika Baru Kabupaten Mimika"

\section{Analisis Kinerja Keuangan}

Kinerja adalah hasil-hasil fungsi pekerjaan atau kegiatan seseorang atau kelompok dalam suatu organisasi yang dipengaruhi oleh berbagai faktor untuk mencapai tujuan organisasi dalam periode waktu tertentu (Tika, 2006:121).

Kinerja juga dipakai sebagai tolak ukur bagi manajemen perusahaan dalam mengambil keputusan. Besar kecilnya kinerja yang dicapai tergantung pada kinerja manajemen perusahaan baik dari masing-masing individu maupun kelompok dalam perusahaan tersebut.

\section{Laporan Keuangan}

Laporan keuangan merupakan suatu bentuk pertanggung jawaban atas kepengurusan sumber daya ekonomi yang dimiliki oleh suatu perusahaan. Laporan keuangan harus disusun berdasarkan standar akuntansi yang berlaku sehingga laporan keuangan tersebut dapat dibandingkan dengan laporan keuangan periode sebelumnya atau dibandingkan dengan laporan keuangan perusahaan lainnya. 
Laporan keuangan menggambarkan pos-pos keuangan perusahaan yang diperoleh dalam suatu periode. Penilaian terhadap suatu kinerja perusahaan biasanya dapat dilakukan analisis terhadap dua komponen laporan kerugian yaitu laporan neraca dan laporan rugi laba.

\section{Teknik Analisis Laporan Keuangan}

Setelah laporan keuangan disusun berdasarkan data yang relevan, serta dilakukan dengan prosedur akuntansi dan penilaian yang benar, akan terlihat kondisi keuangan perusahaan yang sesungguhnya. Kondisi keuangan yang dimaksud adalah diketahuinya berapa jumlah harta (kekayaan), kewajiban (hutang), serta modal (ekuitas) dalam neraca yang dimiliki. Kemudian, juga akan diketahui jumlah pendapatan yang diterima dan jumlah biaya yang dikeluarkan selama periode tertentu. Dengan demikian, dapat diketahui hasil usaha (laba atau rugi) yang diperoleh selama periode tertentu dari laporan laba rugi yang disajikan.

\section{Koperasi}

PSAK Nomor 27 Tahun 2007 menjelaskan bahwa koperasi adalah badan usaha yang mengorganisir pemanfaatan dan pendayagunaan sumber daya ekonomi para anggotanya atas dasar prinsip-prinsip koperasi dan kaidah usaha ekonomi untuk meningkatkan taraf hidup anggota pada khususnya dan masyarakat daerah kerja pada umumnya (Rudianto, 2010:3)
Menurut Undang-Undang Nomor 25 Tahun 1992 dijelaskan pengertian koperasi adalah badan usaha yang beranggotakan orang atau badan hukum kopeasi dengan melandaskan kegiatannya berdasarkan prinsip koperasi sekaligus sebagai gerakan ekonomi rakyat yang berdasar atas asas kekeluargaan (Tunggal, 2002:1). Berdasarkan pengertian tersebut dapat disimpulkan bahwa koperasi merupakan kumpulan orang dan bukan kumpulan modal.

\section{Fungsi, Peran dan Prinsip Koperasi}

Firdaus dan Susanto (2004:43) menjelaskan bahwa di dalam Bab III, bagian pertama Pasal 4 Undang-Undang Republik Indonesia No 25 Tahun 1992 diuraikan fungsi dan peranan koperasi.

\section{Permodalan Koperasi}

Modal merupakan dana yang akan digunakan untuk melaksanakan usahausaha koperasi. Meskipun koperasi Indonesia bukan merupakan bentuk kumpulan modal, namun sebagai suatu badan usaha maka dalam menjalankan usahanya koperasi juga memerlukan modal.

\section{Laporan Keuangan Koperasi}

Laporan keuangan merupakan bentuk pertanggung jawaban atau kepengurusan sumber daya ekonomi yang dimiliki oleh suatu entitas. Penyajian laporan keuangan harus disusun berdasarkan standar akuntansi yang berlaku, agar laporan tersebut dapat dibandingkan dengan 
laporan periode sebelumnya, atau dibandingkan dengan laporan keuangan entitas lainnya.

Kashmir (2010:66) menjelaskan laporan keuangan adalah laporan yang menunjukkan kondisi keuangan perusahaan pada saat ini atau dalam suatu periode tertentu. Kondisi keuangan perusahaan pada saat ini merupakan kondisi perusahaan terkini, yaitu keadaan keuangan perusahaan pada tanggal tertentu untuk neraca dan dalam periode tertentu untuk laporan laba rugi.

\section{Manajemen Koperasi}

Susanto dan Firdaus (2004:84) mendefinisikan manajemen koperasi sebagai cara memanfaatkan segala sumber daya koperasi sebagai organisasi ekonomi secara efektif dan efisien dengan memperhatikan lingkungan organisasi dalam rangka usaha mencapai tujuan organisasi dengan mendasarkan asas-asas koperasi.

\section{Penelitian Terdahulu}

Penelitian ini tidak terlepas dari hasil penelitian-penelitian terdahulu sebagai bahan perbandingan. Penelitian terdahulu menjadi acuan penulis dalam melakukan penelitian, sehingga penulis dapat memperkaya teori yang digunakan dalam mengkaji penelitian yang dilakukan. Namun penulis mengangkat beberapa penelitian sebagai referensi bahan kajian penelitian penulis.

\section{Metode Penelitian}

Penelitian ini dilakukan pada Koperasi Unit Desa (KUD) Langgeng Desa Inauga Kecamatan Mimika Baru Kabupaten Mimika.

Adapun jenis dan sumber data dalam penelitian ini sebagai berikut:

Data primer, merupakan data yang diperoleh secara langsung dari objek penelitian perorangan, kelompok, dan organisasi (Ruslan, 2006:29).

Data sekunder, merupakan data yang diperoleh dalam bentuk yang sudah jadi melalui publikasi dan informasi yang dikeluarkan di berbagai organisasi atau perusahaan, termasuk majalah jurnal, khusus pasar modal, perbankan, dan keuangan (Ruslan, 2006:30).

Dalam penelitian ini, penulis melakukan pengumpulan data dengan teknik sebagai berikut: Riset perpustakaan adalah riset yang dilakukan dengan mencari data atau informasi riset melalui membaca jurnal, buku-buku referensi dan bahanbahan publikasi yang tersedia di perpustakaan (Ruslan, 2006:31).

Wawancara dapat diartikan sebagai percakapan dengan tujuan tertentu. Wawancara dapat dilakukan tidak hanya antara satu pewawancara dengan satu responden, namun juga melibatkan kelompok yang lebih besar dalam waktu yang bersamaan (Efferin, dkk, 2008:316).

Dalam menganalisis kinerja keuangan koperasi, penulis menggunakan beberapa teknik analisis data seperti yang telah dijelaskan, diantaranya Uji Trend, Uji 
Rasio Likuiditas, uji Rasio Solvabilitas , Uji rasio Rentabilitas, dan Uji Rasio Aktivitas.

\section{Hasil Penelitian}

\section{Hasil Analisis Rasio Keuangan}

Berdasarkan dari penelitian yang telah dilakukan berikut ini adalah hasil dan analisis penelitian tentang kinerja keuangan koperasi berdasarkan rasio keuangan.

\section{Analisis Rasio Likuiditas}

Analisis rasio likuiditas bertujuan untuk kemampuan koperasi dalam memenuhi hutang jangka pendeknya. Pemenuhan hutang jangka pendek suatu lembaga dapat dijaminkan dengan jumlah aset yang dimiliki koperasi. Analisis likuiditas ini diukur dengan menggunakan Rasio Lancar (Current Ratio/CR).

Tabel 2 Hasil Perhitungan Analisis Current Ratio (CR) KUD Langgeng) Tahun 20142017

\begin{tabular}{lc}
\hline Tahun & $\begin{array}{c}\text { Current Ratio } \\
(\boldsymbol{\%})\end{array}$ \\
\hline 2014 & 221 \\
\hline 2015 & 272 \\
\hline 2016 & 226 \\
\hline 2017 & 746 \\
\hline
\end{tabular}

Berdasarkan table 2 menunjukkan bahwa pada Tahun 2014 nilai $C R$ yang dihasilkan oleh KUD Langgeng sebesar 221\%. Artinya, setiapRp.1,00 hutang lancar yang dimiliki koperasi dijamin oleh aset lancar sebesar Rp.221. Kemudian di tahun 2015 terjadi kenaikan nilai menjadi $272 \%$, artinya, setiap Rp.1,00 hutang lancar yang dimiliki koperasi dijamin oleh aset lancar sebesar Rp.272. Kemudian penurunan pada tahun 2016 yaitu 226\%. Selanjutnya pada Tahun 2017 mengalami kenaikan sebesar $746 \%$. Hal ini dikarenakan total aktiva lancar yang dimiliki koperasi lebih besar jumlahnya dibandingkan dengan total hutang lancer koperasi.

\section{Analisis Rasio Rentabilitas}

Analisis rasio rentabilitas bertujuan mengukur kemampuan koperasi dalam menghasilkan laba atau Sisa Hasil Usaha (SHU). Hasil Perhitungan Analisis Return on Equty (ROE) KUD Langgeng Tahun $2014-2017$

\begin{tabular}{lc}
\hline Tahun & $\begin{array}{c}\text { ROE } \\
(\boldsymbol{\%})\end{array}$ \\
\hline 2014 & 6 \\
\hline 2015 & 15 \\
\hline 2016 & 26 \\
\hline 2017 & 9 \\
\hline
\end{tabular}

Berdasarkan tabel 4 di atas pada tahun 2014 nilai $R O E$ yang dimiliki KUD Langgeng sebesar $6 \%$, kemudian meningkat pada tahun 2015 menjadi 15\%. Artinya, setiap Rp.1,00 modal sendiri koperasi dapat menghasilkan keuntungan sebesar Rp.0,06 di tahun 2014 dan Rp.0,015 di tahun 2015. Kenaikan nilai ini dikarenakan terdapat peningkatan pada perolehan SHU dan komposisi modal yang dimiliki koperasi di tahun 2014 dan 2015. selanjutnya pada tahun 2016terjadi 
peningkatan lagi menjadi 26\%. Dan pada tahun 2017 mengalami penurunan nilai $R O E$ menjadi 9\%. Penurunan nilai selama kurun waktu 2014 - 2017 menunjukan kinerja keuangan KUD Langgeng masih berada di bawah standar yang telah ditetapkan. Namun dalam hal menghasilkan laba atau SHU dari modal yang dimiliki, koperasi ini cukup baik atau dengan kata lain, koperasi ini dalam menghasilkan $R O E$ cukup rentabel.

\section{Pembahasan}

Berdasarkan tabel 2. menunjukkan bahwa pada Tahun 2014 nilai $C R$ yang dihasilkan oleh KUD Langgengsebesar 221\%. Artinya, setiap Rp.1,00 hutang lancar yang dimiliki koperasi dijamin oleh aset lancar sebesar Rp.221. Kemudian di tahun 2015 terjadi kenaikan nilai menjadi $272 \%$, artinya, setiap Rp.1,00 hutang lancar yang dimiliki koperasi dijamin oleh aset lancar sebesar Rp.272. Kemudian penurunan padatahun 2016 yaitu 226\%. Selanjutnya pada Tahun 2017 mengalami kenaikan lebih sebesar $746 \%$. Hal ini dikarenakan totalaktivalancar yang dimiliki koperasi lebih besar jumlahnya dibandingkan dengan total hutang lancar koperasi.

Dari hasil analisis rasio lancar (Current Ratio) di atas selama kurun waktu 2014-2017 menunjukkan bahwa kinerja keuangan masih berada di atas standar nilai yang ditetapkan. Hal ini dikarenakan jumlah asetlancar yang dimiliki koperasi jauh lebih besar di banding hutang lancar. Sehingga koperasi likuid dalam membayar hutang jangka pendeknya.

\section{Kesimpulan}

Current Ratio $(C R)$ atau rasio lancar merupakan perbandingan antara asset lancar dengan hutang lancar yang dimiliki koperasi. Ada standar Berapa Besar nilai Current Ratio yang paling baik, namun Untuk Prinsip kehatian-kehatian besarnya $200 \%$ atau 2:1 di anggap Baik

Return on Equity (ROE) adalah perbandingan antara Sisa Hasil Usaha dengan jumlah modal sendiri. Rasio ini menunjukan kemampuan modal dalam menghasilkan laba atau Sisa Hasil Usaha (SHU) koperasi. Berdasarkan hasil perhitungan analisis ROE di atas terlihat bahwa nilai ROE yang dimiliki oleh KUD Langgeng selama periode 2014 2017 berfluktuasi.

Debt to Asset Ratio (DtAR) adalah perbandingan antara total hutang terhadap total aset. Rasio ini digunakan untuk mengetahui seberapa bagian aset yang digunakan untuk menjamin hutang koperasi. Adapun standar nilai rasio ini menunjukkan nilai relative antara nilai total utang terhadap total aktiva. Rasionya dihitung dengan membagi nilai total utang dengan total aktiva.

\section{Saran}

Untuk meningkatkan likuiditas, sebaiknya perlu mengurangi dan menekan jumlah hutang lancar serta lebih meningkatkan aset lancar.

Untuk meningkatkan rentabilitas (SHU), perlu melakukan pengendalian dan penggunaan aset seoptimal mungkin dengan cara meningkatkan penghasilan/ laba tanpa diikuti dengan kenaikan 
biaya-biaya atau dapat menekan seluruh

biaya operasional koperasi, sehingga mampu menghasilkan SHU yang lebih besar serta dapat memberikan jaminan terhadap hutang yang lebih besar.

\section{Daftar Pustaka}

Agus Sartono, Manajemen Keuangan Teori dan Aplikasi, Edisi Ketiga, Penerbit BPFE, Yogyakarta, 2016.

Harahap, Sofyan Syafri. 2012. Analisis Kritis Atas Laporan Keuangan. Edisi Pertama. Jakarta: Raja Grafindo Persada.

Kuswadi, Cara Mudah Memahami Angka-Angka Dan Manajemen Keuanga Bagi Orang Awam. Ekex Media Komputindo. 2014

Kasmir. 2012. Pengantar Manajemen Keuangan. Jakarta: Raja Grafindo Persada.

Partomo, Tiktik Sartika dan Soejoeno, Abdul Rachman. 2013. Ekonomi Skala Kecil dan Menengah dan Koperasi. Bogor: Ghalia Indonesia.

Sawir, Agnes, Analisis Kinerja Keuangan dan Perencanaan Keuangan Perusahaan, Penerbit PT. Gramedia Pustaka, Jakarta, 2015. 